\title{
Intensive Forestry on the West Coast ${ }^{1}$
}

\author{
by \\ J. Harry G. Smith²
}

\begin{abstract}
Intensive forestry on Canada's West Coast has some impressive accomplishments but re-investments of timber capital must increase many times to meet future needs. Intensive forest management requires greatly increased inputs of labour, capital, and knowledge in order to enhance the amount and value of yields from an ultimately limited land base. Attractive incentives must be developed for private land owners and users of public forest lands to sustain current yields of wild stands, to avoid a falldown in harvest as surplus old growth values are liquidated, and to make up for withdrawals from the land base and complications of timber management.

Since 1912-13 direct B.C. government forest revenues have exceeded expenditures to 1976 by $\$ 847$ million. British Columbians and many other Canadians are therefore deeply in debt to the forests of British Columbia, and soon should re-invest past surpluses to help build a base for even greater returns in future.

Past trends, the current situation, relation to other areas, costs, responses, sources of funds, multiple use implications, alternatives, research needs, and incentives, are discussed with special reference to the Vancouver Forest District.
\end{abstract}

\section{Introduction}

Improved forest land management is needed to sustain current harvests of wild stands, to avoid a falldown in cut as surplus old growth values are liquidated, and to make up for withdrawals from the land base and complications of management. Intensive forest management increases inputs of labour, capital, and knowledge in order to enhance the amount and value of yields from a relatively fixed land base. Drawing on a decade of high-yield forestry experience, Bingham (1976) reported the following absolute prerequisites: clear and consistent direction, continuous commitment from the top, firm management objectives, high technological capability, numerous well trained people a tremendous and accurate data blank, top-flight research programs, and consistent funding. Of course it also helps to own your land as Weyerhaeuser does.

Intensive timber management started in British Columbia in the Vancouver Forest District (VFD) because it is most productive. The VFD includes 12.7 million acres of timberland, which is a large part of the Coast total of 19.5 million acres. Interior timberlands as of 1973 (B.C.F.S. 1975) amounted to 109.2 million acres. The 1973 B.C. total timberland area of 128.7 million acres is still being reduced by withdrawals for nontimber purposes and by deferrals of timber harvests on "sensitive" sites.

This paper focuses on the "West Coast of B.C. and updates the information on B.C. and Sweden reported by Reed (1978). It presents an optimistic view of the potential gains from intensive forest management. It concludes that sustained commitment of resources by government and industry, much more research, and enhanced public recognition of the need for re-investment in timber management, are essential.

\section{Past Trends}

Table 1 records changes in area logged, burned, and planted in the Vancouver Forest District for 1946, 1956, 1966, and 1976. Areas logged peaked at around 100,000 acres in the mid-1960's. Wildfires decreased remarkably from about 10,000 acres a year in 1946 and 1956. Slashburning and improved fire control reduced accidentally burned, and reburned, areas in slash from about 3,000 acres to almost nothing recently. In the 1930's, accidental burning and reburning of slash, as well as young stands, was so common that there was little chance of successful regeneration. Fire losses now are highly variable and in some years have jeopardized sustained yield programs in some types and regions of B.C. (Smith and Gilbert 1976). Area planted has increased 463\% since 1946.

Remarkable increases in utilization have taken place since 1946 (Table 2). Over the past 30 years scaled cut (but not depletion because there has been a decrease in quality of stands logged) has increased $168 \%$. Volume utilized per acre has increased $99 \%$ and the price of stumpage has increased $329 \%$.

\section{Current Situation}

Table 3 records areas by ownership, growth and site classes in the VFD and shows that it includes the bulk of the privately controlled land on the Coast. The areas and mean annual increments

\footnotetext{
1 Prepared for the Intensive Forestry Session of the Canadian Institute of Forestry, Vancouver, B.C., October 6, 1977. Helpful information and data were provided by: A. V. Backman, H. J. Benskin, P. Brett, J. Bruce, B. Devitt, J. A. F. Gardner, W. Leesing, F. T. Leslie, E. H. Lyons, D. H. McQuillan, B. Palmer, S. Rasmussen, W. Smith, O. Sziklai, and J. Toovey.

2 Professor, Faculty of Forestry, University of British Columbia, Vancouver,B.C.
} 
Table 1 - Past Areas Logged, Burned, and Planted in the Vancouver Forest District - Acres

\begin{tabular}{|c|c|c|c|c|c|c|}
\hline \multirow[b]{3}{*}{ Year } & \multirow[b]{3}{*}{ Logged } & \multirow[b]{3}{*}{ Wildfire } & \multicolumn{3}{|c|}{ Burned } & \multirow[b]{3}{*}{ Planted } \\
\hline & & & \multicolumn{3}{|c|}{ Slashburn } & \\
\hline & & & $\begin{array}{c}\text { Once } \\
\text { on purpose }\end{array}$ & $\begin{array}{c}\text { By } \\
\text { Accident }\end{array}$ & $\begin{array}{l}\text { Twice by } \\
\text { Accident }\end{array}$ & \\
\hline 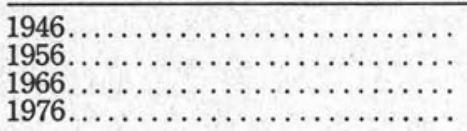 & $\begin{array}{c}58,502 \\
90,661 \\
100,067 \\
78,777^{2}\end{array}$ & $\begin{array}{r}10,570 \\
11,171 \\
667 \\
280\end{array}$ & $\begin{array}{l}25,498 \\
19,551 \\
66,358 \\
82,933^{3}\end{array}$ & $\begin{array}{r}2,174 \\
2,872 \\
188 \\
22\end{array}$ & $\begin{array}{r}605 \\
512 \\
32 \\
0\end{array}$ & $\begin{array}{c}10,707 \\
5,339 \\
39,887^{1} \\
60,276\end{array}$ \\
\hline
\end{tabular}

1Includes Prince Rupert coast planting.

2Includes 2,574 acres of partial cutting.

${ }_{3} \mathrm{~A}$ good year for slash burning in which the gross area shown was treated: $40.7 \%$ broadcast, $34.3 \%$ spot burned, $2.1 \%$ bunched and burned and on $22.9 \%$ only landings were burned.

Table 2 - Volumes Logged and Stumpage Prices in the Vancouver Forest District

\begin{tabular}{|c|c|c|c|c|c|c|}
\hline \multirow[b]{2}{*}{ Year } & \multicolumn{5}{|c|}{ Volume Cut } & \multirow{2}{*}{ Stumpage } \\
\hline & MM cf & $\%$ & cf/ac & $\%$ & $\$ /$ Gef & \\
\hline 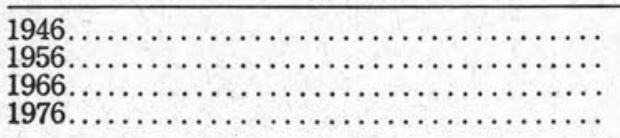 & $\begin{array}{l}362.9 \\
583.6 \\
778.1 \\
973.3\end{array}$ & $\begin{array}{l}100 \\
161 \\
214 \\
268\end{array}$ & $\begin{array}{r}6,202 \\
6,439 \\
7,776 \\
12,355\end{array}$ & $\begin{array}{l}100 \\
104 \\
125 \\
199\end{array}$ & $\begin{array}{l}1.63 \\
5.78 \\
6.76 \\
7.00\end{array}$ & $\begin{array}{l}100 \\
355 \\
415 \\
429 \\
\end{array}$ \\
\hline
\end{tabular}

Table 3 - Areas by Ownership, Growth and Site Classes, VFD

\begin{tabular}{|c|c|c|c|c|c|c|}
\hline \multirow[t]{2}{*}{ Ownership Class $^{1}$} & \multicolumn{6}{|c|}{ Site Class } \\
\hline & Good & Medium & Poor & Low & $\begin{array}{l}\text { Total } \\
\text { VFD }\end{array}$ & $\begin{array}{c}\text { Total } \\
\text { Coast }\end{array}$ \\
\hline 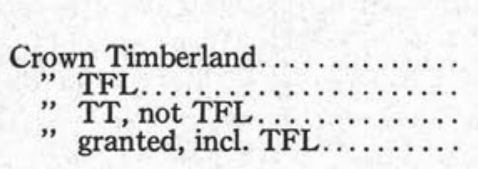 & $\begin{array}{r}187 \\
716 \\
45 \\
179\end{array}$ & $\begin{array}{r}2,302 \\
2,079 \\
325 \\
978\end{array}$ & \multicolumn{2}{|c|}{$\begin{array}{cc}\text { Area, } & 000 \text { acres, } \\
2,572 & 3973 \\
856 & 212 \\
168 & 14 \\
1,013 & 132\end{array}$} & $\begin{array}{r}5,453 \\
3,862 \\
553 \\
2,301\end{array}$ & $\begin{array}{r}10,096 \\
5,466 \\
794 \\
2,416\end{array}$ \\
\hline \multicolumn{7}{|c|}{ Mean annual increment ${ }^{2}$ of immature stands, $\mathrm{cf} / \mathrm{ac} / \mathrm{yr}$. } \\
\hline 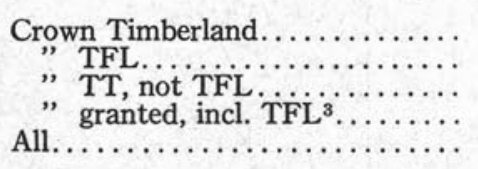 & $\begin{array}{l}120 \\
137 \\
135 \\
127 \\
131\end{array}$ & $\begin{array}{l}86 \\
93 \\
87 \\
91 \\
89\end{array}$ & $\begin{array}{l}42 \\
46 \\
44 \\
45 \\
43\end{array}$ & $\begin{array}{l}18 \\
18 \\
17 \\
17 \\
17\end{array}$ & $\begin{array}{l}68 \\
98 \\
75 \\
74 \\
77\end{array}$ & $\begin{array}{l}66 \\
95 \\
76 \\
74 \\
76\end{array}$ \\
\hline \multicolumn{7}{|c|}{ Median height, Dom. and Codom. at 100 years, $\mathrm{ft}}$. \\
\hline All....................... & 155 & 115 & 75 & 40 & 107 & 106 \\
\hline
\end{tabular}

1Tree Farm Licence (TFL), temporary tenures (TT) outside TFL, and Crown granted lands including those in TFL's.

2Includes all trees larger than 9.0 inches $\mathrm{dbh}$ and sound wood volume between a 1 -foot stump and a 4-inch top.

3Because old cruises were used, productivity of these lands probably is underestimated.

of immature stands reported by ownership classes (B.C.F.S. 1975) are given to indicate relative productivity and extent of the major tenure classes. The average mean annual increment of immature stands in the VFD is 77 cubic feet, to a close utilization standard. Median heights for each site class given at the bottom of the table suggest that heights of dominant and codominant trees, at age 100, will average 107 feet. If all timberlands (12.7 million acres) in the VFD grew usable wood at the average rate of immature wild stands, a total of 978 million cubic feet of wood would just balance the 1976 cut. In order to provide for future generations yields must be increased sub- stantially in both value and volume.

Data summarized recently by the B.C.F.S. Productivity Committee show proportions of immature forests by age, site, and ownership classes. The average site of Public Sustained Yield Units (PSYU's) at 97 feet is considerably lower than the 128 for Tree Farm Licences (TFL's), and 115 for Tree Farms (TF's). Obviously, the best Crown lands were included in TFL's. Although it is traditional to think that existing stands will provide a transition from old growth, some may be less attractive than younger man-made forests. At least one company is planning rotations of 45 to 55 years for its plantations, and rotations as short 
as two to 10 years are being examined for poplars (Armson and Smith 1978).

Table 4 compares Vancouver and Prince Rupert Forest District intensive management activities with those for all of B.C.

Table 5 records the coastal forestry activities of five companies up to the end of 1976. There are substantial differences among them. The first company to develop an intensive forest management program, MacMillan Bloedel (MB), has some impressive accomplishments to date (Leesing 1975). MB has stressed spacing and cleaning, conifer release, and commercial thinning. $M B$ has a current backlog area, which is only about 2.7 times the area logged annually, to be treated by its on-going programs. Both $\mathrm{MB}$ and Crown Zellerbach (CZ) have recently announced major investments for improving their manufacturing and logging capabilities and will need more timber to sustain and expand their operations. Tahsis has almost no backlog on its TFL No. 19, because it plants immediately following logging of most settings. Tahsis has provided leadership in tree improvement and other areas (Smith 1977f). Pacific Logging Company (PLC) manages its self-regulated Crown-granted lands very intensively, stressing planting and fertilization, and spending about $\$ 3.00$ per acre owned, annually. Not all plantations are successful. PLC experience suggests that only about $80 \%$ of the areas planted will be adequately stocked. Tahsis planting includes about $24 \%$ "fill-planting", so gross areas should be reduced appropriately. About $10-15 \%$ of B.C. Products' planting is replanting or interplanting.

Slash burning, snag felling, and similar activities considered a part of logging, are not recorded here. There are large annual variations in the size and nature of programs. MB now is reducing and reviewing its spacing and cleaning because many backlog areas have been treated, and future profitability must be reconsidered with the rapidly increasing minimum hourly woods wage, now $\$ 7.36$. CZ is planning to expand its spacing and cleaning following a review of their economics in 1975. By 1978, CZ may be spacing five to seven thousand acres and fertilizing seven to ten thousand acres annually. Although little commercial
Table 4 - Area Clearcut, Planted, Stand Treated, Regeneration Surveyed and Burned in 1976: Acres

\begin{tabular}{|c|c|c|c|}
\hline Activities $^{1}$ & VFD & PR FD & All B.C. \\
\hline Clearcut. & 76,203 & 40,309 & 329,322 \\
\hline Selective Cut. & 2,574 & 4,693 & 58,560 \\
\hline Total Cut. & 78,777 & 45,002 & 387,882 \\
\hline FS planted on CL \& CGL. & 11,665 & 11,650 & 60,727 \\
\hline Cos. " TSL's TSHL's & 4,597 & 3,802 & 39,222 \\
\hline TFL's.......... & 27,630 & 3,205 & 38,118 \\
\hline Cos. " & 2,497 & 17 & 2,514 \\
\hline Cos. & 4,040 & - & 5,280 \\
\hline other privates.. & 9,847 & & \\
\hline 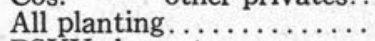 & 60,276 & 18,674 & 155,708 \\
\hline PSYU clearcut.... & 30,675 & 27,906 & 248,946 \\
\hline planted. & 16,262 & 18,674 & 111,557 \\
\hline " conifer release & 805 & 216 & 1,477 \\
\hline "juvenile spacing. & 1,702 & 132 & 3,075 \\
\hline$"$ mistletoe control...... & 168 & & 2,254 \\
\hline$"$ regen. survey FS..... & 62,966 & 73,615 & 371,230 \\
\hline S............ & 48,1 & 64,164 & 235,530 \\
\hline$"$ NSR, FS. & 14,720 & 9,451 & 134,964 \\
\hline Wildfires. & & 185 & 140,839 \\
\hline Slashfires (gross). & 82,933 & & 299,330 \\
\hline
\end{tabular}

1Although both the Vancouver and Prince Rupert Districts include some interior forests, both represent coastal activities for comparison with all of B.C.

Forest Service (FS) planting is primarily on Crown land. Company planting is on timber sale licences, timber sale harvesting licences, tree farm licences, crown grants and tree farms. Public sustained yield unit (PSYU) reported to show satisfactory regeneration, not satisfactory regeneration, and non-productive areas.

thinning is feasible now, by the year 2000 it might make an important contribution. Prospects for thinning will improve with research in thinning methods, higher log prices, and installation of small log processing equipment.

Many important activities are not included in Table 5. Classification of land for management, regeneration surveys, applied and developmental research, and programs such as tree improvement, are given special emphasis by various firms and agencies. For example, the pioneering tree improvement efforts by Tahsis and Pacific Logging now are producing some excellent yields of improved seed. BCFP is expanding its spacing and increasing management intensity greatly.

\section{Some Comparisons With Other Regions}

Our largest forest company, MacMillan Bloedel, with justifiable pride, celebrated planting of its

Table 5 - Planting and Stand Management by Some Representative Companies ${ }^{1}$ to the end of 1976: Acres, B.C. Coast.

\begin{tabular}{|c|c|c|c|c|c|}
\hline \multirow[b]{2}{*}{ Activities } & \multicolumn{5}{|c|}{ Companies } \\
\hline & MB & $\mathbf{C Z}$ & $\begin{array}{c}\text { Tahsis } \\
\text { TFL } 19\end{array}$ & PLG & BCFP \\
\hline Planting. & 249,890 & 83,766 & 40,731 & 56,000 & 118,711 \\
\hline Site Preparation (hardwood seed tree control). & 57,694 & 1,320 & 25,892 & 242 & 3,355 \\
\hline Spacing and Cleaning. $\ldots \ldots \ldots \ldots \ldots \ldots \ldots$ & 75,119 & 15,730 & 3,106 & $1, \overline{7} 67$ & 15,768 \\
\hline Release of Conifers............... & 37,602 & 7,500 & 1,538 & 160 & 14,527 \\
\hline Fertilization................. & 3,034 & 1,230 & - & 26,109 & 1,180 \\
\hline Commercial Thinning $\ldots \ldots \ldots \ldots \ldots \ldots \ldots \ldots$ & 11,577 & 160 & - & - & 250 \\
\hline Site Rehabilitation.................... & 2,370 & 2,370 & - & 2,396 & \\
\hline Mistletoe Control.. & - & - & - & 998 & \\
\hline
\end{tabular}

1MacMillan Bloedel and Crown Zellerbach data are for all tenures on the coast of B.C. The Tahsis Tree Farm Licence is on the west coast of Vancouver
Island. The Pacific Logging Company Crown-granted and self-regulated lands are on southeast Vancouver Island. In addition, MB has seeded 6,445 and PLC
2,996 acres. The MB total includes 4,859 acres planted by the BCFS before inclusion in TFL's B.C. Forest Products data are for all tenures on the coast
of B.C. Cite preparation includes scarification. BCFP did 518 acres of direct seeding. PLC planted 82,703 and seeded 6,482 acres to create the net areas reported above. 
100 millionth seedling in May, 1976, ten years after its 50 millionth tree was planted in April, 1966. MacMillan Bloedel led the Pacific Northwest when it began its "intensive forestry" program in 1963, and has made impressive accomplishments in management of its 2.8 million acres of productive forest land in B.C. (Leesing 1975). The MB record compares favourably with many industrial tree farms in northwest U.S.A. (Hagenstein 1977) but is modest in relation to the leading U.S. company, Weyerhaeuser. In 1975 Weyerhaeuser planted 64.5 million trees on its 2.8 million acres in the west (Bingham 1976). In 1976 Weyerhaeuser planted 185 million seedlings on its total land area of 5.6 million acres including the south. "Owning less than $1 \%$ of the country's commercial forest base, it does $16 \%$ of all the nation's forest regeneration." (Griffith 1977). Weyerhaeuser U.S.A. has outperformed all forestry firms and agencies in British Columbia.

In 1976 on the coast of British Columbia, 28,5 million trees were planted on 68,000 acres, and in the Interior, 44.4 million trees were planted on 87,000 acres.

The total planted to the end of 1976 on the coast was 457 million trees, and in the interior, 206 million trees. These numbers look large but during 1976 Sweden planted $2 / 3$ of the total to date in B.C., with its 450 million seedlings on 445,000 acres. The area planted with Canadian lodgepole pine in Sweden to 1976 amounted to 161,000 acres.

The Swedish situation is so remarkable that it merits detailed examination as a target for British Columbians. The 1975 data are available through the National Board of Forestry (1977). From its 58.1 million acres of forest land, Sweden cut $1,995,280,550$ cubic feet of solid wood which is almost identical to B.C.'s average cut for the decade ending in 1976. In 1976 Sweden clearcut 531,498 acres, all of which were prepared for regeneration. The final fellings represented $71 \%$ and thinnings $29 \%$ of the total cut. Clearcutting yielded 2,628 cf/ac from trees which average 79 feet at age 100 . The cut represented $2.87 \%$ of the growing stock. Growth slightly exceeded harvest, but in the next two decades problems will result from an imbalance of age classes and past overcutting.

Forestry obviously is intensive now, and will improve greatly in future (Andreason 1977). For every 100 acres clearcut, 100 were prepared for regeneration, 119 were spaced, 74 fertilized, 9 sprayed with herbicides, one burned broadcast, 61 scarified, one burned by wildfires, 74 planted, two seeded, and 14 drained. Beneficial activities were practised on 4.54 acres for each one cut. A high degree of mechanization of forestry work is evident, with man days per cunit decreasing from 2.35 in 1957 to 0.4 in 1975 . Sustained efforts are needed to create similar improvements in Canada (Silversides and Haig 1977). The forest owner's gross earnings averaged $\$ 51$ per cunit, and stumpage prices paid were about $\$ 60$ per cunit of solid wood.
In some respects, timber management in Finland was even more important and more intensive (Reed 1978).

Comparisons with other regions are always complicated by variations in attitudes, institutional requirements, and local circumstances. For example, because its past emphasis has been on hazard abatement, slash burning is not included in the intensive forestry accomplishments for coastal B.C. which are shown in Table 5. In 1976, excluding slashburning, $\mathrm{MB}$ treated 97 acres for every 100 logged. Most intensive was Pacific Logging Company (PLC) which in 1976 treated 250 acres for every 100 logged. Tahsis treated 98 acres for every 100 logged in 1976, but provided leadership in other respects (Smith 1977f). In the PSYU's of the VFD the B.C. Forest Service was responsible for treatment of about 62 acres for every 100 logged.

\section{Plans for Expansion of Programs}

Some company plans have been mentioned. The B.C. Forest Service is also well aware of the need to intensify management. The Reforestation Division is seeking approval for increased seed orchard programs and accelerated planting. The Forest Productivity Committee has suggested administrative procedures and goals for bringing together Districts and Divisions to improve forest management. The Special Studies Division is developing a plan for multiple-purpose management of the many plantations and other young stands on the Sayward Forest which should be appropriately revised after public review.

\section{Costs of Intensive Management}

Some financial and social implications of intensive forest management were reviewed by Devitt and Schon (1977). They estimated that the total annual silvicultural expenditures from all sources were $\$ 28$ million or $\$ 0.31$ per productive acre. Their minimum crop tending program would cost $\$ 1.70$ annually for 90 million acres or $\$ 150$ million and they would like to see expenditures increased to $\$ 300$ or $\$ 400$ million annually. Such sums contrast remarkably with the generally low level of re-investment in Canadian silviculture documented by Weetman (1977).

\section{Treatment Responses}

Examples and analyses of responses to intensification of management are preliminary but encouraging (DeBell 1977). Appropriate size and high quality of planting stock are vital. Trees which reach breast height rapidly can greatly expand their juvenile height growth advantages (Smith 1976a).

Estimates of expected gains from cultural practices, expressed as a percentage of average yield from wild stands, vary widely (Smith 1977e). Responses depend on intensity, timing, and nature of treatment, and the extent to which their effects 
are additive. For Douglas-fir, the best estimates for an "optimum" regime of planting, fertilization, genetically superior stock, spacing and commercial thinning, suggest that wild stand yields will be exceeded by 100 to 160 per cent. The Wind River (Reukema 1977) and U.B.C. Research Forest (Smith 1977c) spacing trials suggest that such estimates may be conservative. Spacing control has a dramatic effect on merchantable yields. There is a high priority need to develop estimates of probable trends in stocking and stand density and upper limits to numbers of trees that can be supported without excessively slowing individual tree growth. Because of low percentage crown cover and low numbers of trees per acre observed in average natural stands, it appears reasonable that achievement of full stocking and optimum density could double the yields observed for natural stands (Smith 1977d). Spurr (1976) has suggested that, under intensive management and full utilization, U.S.A. timber yields could be quadrupled.

\section{Where Should the Money Come From?}

In the early 1900's forest revenues helped save British Columbia from bankruptcy (Smith 1976b). Since 1912-13, when B.C. Forest Service expenditures were only $10.4 \%$ of forest revenues, the share has climbed gradually. In 1974-75 revenues exceeded expenditures by 70 million.

In fiscal year 1975-76, for the first time, B.C. Forest Service expenditures exceeded revenues substantially. At \$86.6 million Forest Service costs were $\$ 36.7$ million or $73.4 \%$ greater than income. This deficit looks small in relation to the $\$ 847 \mathrm{mil}$ lion excess of revenues over forest service expenditures since 1912-13. Of course there would be at least as much contributed indirectly. Obviously British Columbians and all Canadians are deeply in debt to the forests of British Columbia and should treat them better in future.

\section{Multiple Use Implications}

As management becomes more complicated and the land base for timber is diminished by the concerns for land uses other than timber, needs for intensification of land management increase. For much too long single purpose forest land uses and withdrawals from the timber land base have been seen as the best way out of conflicts. From now on all changes in tenures and management should be justified by careful analysis of all the costs and all the benefits.

We must develop new methods for evaluation of damage, management complications, and withdrawals based primarily upon the costs of replacing the accumulated volumes and timber growing capacity. In parts of the Northwest stumpage values are $\$ 70.00$ a cunit, money is worth $5 \%$ annually, and two cunits per acre are grown each year. There, with the gross timber growing value per acre of $\$ 2,800$ and annual growth of $\$ 140$, timber can provide effective competition for most other uses and users.

\section{Improved Timber Processing and Conversion}

Improved timber management is just one possibility for increasing usable supplies of timber (Rich 1977). Immediate increases also can be obtained by development of new products, new methods, and new markets for making better and more complete use of existing trees and stands. The allowable cut effect based upon improved cultural practices also facilitates treatment of reinvestments in timber management as costs. As long as there is a surplus of mature timber, and forests have been regulated conservatively, the effects of intensified management can also be captured immediately.

Carrying short rotation and intensive utilization concepts to their ultimate level Smith (1977) has proposed farming of red alder to allow flexible appropriation of yields to a spectrum of potential uses including energy.

\section{Some Research Needs}

One reason for lack of performance is lack of knowledge. Many aspects of intensified forest management are still poorly understood in B.C. (Smith 1977b) and should be carefully researched. Bingham (1976) has suggested that special expertise and data are needed in the areas of thinning techniques and impacts, forest growth and yields, soils, fertilization, and forest genetics. We have a start on these for Douglas-fir and western hemlock on the South Coast but we know much less than necessary about our other species and regions.

A vital but neglected area is the costs and benefits of improving quality of Pacific Northwest species. With increasing values for clear wood, it seems essential that the long-term demand be studied and, if promising, operational pruning should be stressed (Smith 1977a). It is not even an allowable forestry cost now. The profitability of some investments in timber management probably is being diminished by current practices. The emphasis on rather dense stands, continuing plans for at least one "commercial" thinning, and considerable vagueness about premiums for log quality and tree size, could be locking timber managers into expensive stocking control and unprofitable harvesting situations. Renewed emphasis on the importance of increasing piece size in future harvests is essential. At present in B.C., only very broad size classes are used and appraisals do not reflect fully the extra costs of handling small logs and trees.

Research in forest economics is still neglected. Improvement of financing and investment functions is the next logical step in the evolution of timber management planning (Murphy 1977). This depends on there being more expertise. There 
should be a forest economist on staff in each Forest District with strong research support from B.C. Forest Service headquarters staff in Victoria.

\section{Incentives are Essential}

Too little Public Sector encouragement and support are given to intensification of forest land management in B.C. Timber-growing incentives are needed for private land owners and managers of publicly-owned lands (Rich 1977).

Implementation of the best features of the Pearse Report (1977) should help to replace regulations with incentives and to increase the general level of support for intensive management.

One of the best incentives for improved timber growth is an increase in value of stumpage. New Zealand and the Pacific North-west States have enjoyed very high stumpage values, partly as a result of log exports to Japan. B.C. timber growers also should consider possible gains from log exports, which might subsidize logging and rehabilitation of low quality stands.

The Productivity Committee of the B.C. Forest Service has encouraged research and developed some incentives for intensification of management which should be increased substantially. Cooperative programs in tree improvement and reforestation should be encouraged.

\section{Political Commitment is Growing}

Intensive timber management requires political involvement at all levels on a perpetual basis. The Scandinavians have a well-developed awareness of the need for better timber management and we can learn much from them. We also should emulate the "salmonid enhancement" program by developing improved public understanding and support for intensified forest management. The Reed (1978) study may provide a good foundation for creating new awareness and new FederalProvincial initiatives.

Silversides and Haig (1977) observed that "all sectors of the forestry community (and a substantial portion of the general public) are aware of the urgent need for more intensive and effective management."

\section{Conclusions}

This is an exciting time for forest land managers. Results of early efforts are becoming apparent in more successful plantations, well cultivated stands, genetically improved stock, and expanding programs. There are encouraging indications that yields from wild stands can be doubled in volume and improved greatly in value by vigorous implementation of optimum management regimes. Some early dreams have already become reality. British Columbians are fortunate in that many aspects of intensified forestry can be supported simply by appropriately re-investing timber capital available from accelerated rates of harvest. Greatly expanded re-investments are needed, however, just to sustain the present levels of harvest.

The necessary public expenditures will not be made unless timber managers also do a good job of land management in association with other resource users, so the total costs will be high. It will also cost something to encourage private land managers to increase their performance.

Even the most intensively managed forest lands in B.C. fall short of the average for all Sweden. Excluding preparation for regeneration after logging, our best management treats 2.50 acres for each one logged while the Swedes average 3.54 acres treated for each one cut.

Progress has been commendable, but existing programs should be improved and expanded greatly in British Columbia.

\section{References}

Andreason, O. 1978. Future forest management trends in Sweden. For. Chron. 54 (1)

Armson, K. and J. H. G. Smith, 1978. Management of hybrid poplar. Reed and Associates, Vancouver, Forest Management in Canada, Case Study 5.

B.C. Forest Service, 1975. Forest inventory statistics of British Columbia (1973). Inventory Div., Victoria.

B.C. Forest Service. 1977. Forest Service annual report 1976 statistics. Information Div. Victoria.

Bingham, C. W. 1976. Increasing Douglas-fir forest growth one company's experience. Weyerhaeuser, Tacoma.

DeBell, D. S., A. P. Brunette and D. L. Schweitzer. 1977. Expectations from intensive culture on industrial forest land. Jour. For. 75(1): 10-13.

Devitt, W. J. B. and D. O. L. Schon. 1977. People, jobs, and timber supply maintenance in British Columbia. A proposa prepared by the Canadian Institute of Forestry, Vancouver Island Section.

Griffith, T. 1977. Weyerhaeuser gets set for the 21st century. Fortune, April, 75-88.

Hagenstein, W. D. 1977. Tree farms - greener every year. Univ. of B.C., Fac. of For., H. R. MacMillan Lecture.

Johnson, C. M. 1977. Plantation forestry in British Columbia. Pulp and Paper Can. 78(12): 57-9.

Leesing, W. 1975. MacMillan Bloedel's intensive forestry program. CPPA, Woodlands Section, Montreal, 2865(G-1): 19-23.

Murphy, P. A., J. C. Fortson and J. E. Bethune. 1977. Timber management decision-making under imperfect capital markets. Amer. Jour. of Agric. Econ. 59(2): 302-10.

National Board of Forestry. 1977. Statistical yearbook of forestry 1975. Stockholm.

Pearse, P. H. 1976. Timber rights and forest policy - 1976. Queen's Printer, Victoria, Vols. I and II.

Reed, F. L. C. and Associates. 1978. Forest management in Canada. Forest Management Institute, CFS, Ottawa, Vols. I and II.

Reukema, D. L. 1977. The Wind River Douglas-fir spacing trial. USFS, Olympia.

Rich, S. U. 1977. Measures for expanding the effective timber supply. For. Prod. Jour. 27(4): 10.

Silversides and Haig. 1977. Mechanization of silviculture in Canada. Pulp and Paper Canada 78(6): 37-46.

Smith, J. H. G. 1976a. Big stock vs. small stock. Western Forestry and Conservation Assoc., Portland, Proceedings 1075: 107-115.

Smith, J. H. G. 1976b. Investment implications of sustained yield theories and criteria for improving forest land management. In Timber Policy Issues in B.C., U.B.C. Press: 142-70. 
Smith, J. H. G. 1977a. Costs and benefits of improving quality of young stands of Douglas-fir, western hemlock and western red-cedar. Univ. of B.C., Fac. of For.

Smith, J. H. G. 1977b. Need for research into intensified forest management. Univ. of B.C., Fac. of For.

Smith, J. H. G. 1977c. Results of U.B.C. spacing trials to age 20. Univ. of B.C., Fac of For.

Smith, J. H. G. 1977d. Yield estimates and preliminary guides for spacing and thinning British Columbia forests. Univ. of B.C., Fac. of For.

Smith, J. H. G. 1977e. Management of Douglas-fir and other forest types in the Vancouver Public Sustained Yield Unit. Reed and Associates, Vancouver, Forest Management in Canada, Case Study 4.
Smith, J. H. G. 1977f. The Tahsis Tree Farm Licence - A Canadian Co-Operative Sustained Yield Unit. Univ. of B.C., Fac. of For.

Smith, J. H. G. and D. E. Gilbert. 1976. Rates of spread and fire damage to timber cover types in British Columbia. Proceedings: Annual Tall Timbers Fire Ecology Conference No. 15: 135-54.

Smith, N. J. 1977. Red alder as a potential source of energy. Univ. of B.C., Fac. of For.

Spurr, S. H. 1976. American forest policy development. Univ. of Wash. Press, Seattle.

Tahsis Co. Ltd. 1977. Annual report tree farm licence No. 19. Vancouver.

Weetman, G. F. 1977. Expenditures and decision-making in Canadian silviculture. Pulp and Paper Canada 78(1): 61-5. 